\title{
Konflik Keluarga Betawi dalam Cerpen Belum Selesai Karya S.M. Ardan dan Dzikir Karya Chairil Gibran Ramadhan: Suatu Perbandingan
}

\author{
Rizki Ramadhan \\ UIN Syarif Hidayatullah, Jakarta, Indonesia \\ ramadhan.rizki2814@mhs.uinjkt.ac.id
}

\begin{abstract}
Literature is a reflection of life. It is generally indentified from what has been presented in literary works, especially prose. This may be found through the research of literary works that observe the socio-cultural reality in society. This study aimed to determine the types of conflicts and their contributing factors in the short stories entitled Belum Selesai by S.M. Ardan and Dzikir by Chairil Gibran Ramadhan. The method used in this research was descriptive qualitative. The approach in this research was comparative literature by comparing two different short stories. The material object used in this research was short stories entitled Belum Selesai by S.M. Ardan, and Dzikir by Chairil Gibran Ramadhan, while the formal object in this research was using conflict theory, and the factors causing a conflict. The data collection technique used in this research was a literature study. The results of this study included the types of conflicts and the factors that caused them to happen. The type of conflicts in the stories was the conflict between a husband and his wife. The causes of conflict were religious and occupation issues.
\end{abstract}

Keywords: chairil gibran ramadhan, betawi family, conflict, s.m. ardan, comparative literature

Abstrak : Sastra merupakan sebuah refleksi dari kehidupan. Refleksi tersebut dapat diketahui dari apa yang disajikan di dalam karya sastra, khususnya prosa. Hal ini ditemukan melalui penelitian karya sastra yang mengupas kondisi sosial-budaya masyarakat. Penelitian ini bertujuan untuk mengetahui bentuk-bentuk konflik serta faktor penyebab munculnya konflik dalam cerpen Belum Selesai karya S.M. Ardan dan Dzikir karya Chairil Gibran Ramadhan. Metode yang digunakan dalam penelitian ini adalah deskriptif kualitatif. Pendekatan yang digunakan dalam penelitian ini adalah sastra bandingan dengan cara membandingkan cerpen yang satu dengan cerpen lainnya. Objek material dalam penelitian ini adalah cerpen Belum Selesai karya S.M. Ardan dan Dzikir karya Chairil Gibran Ramadhan. Objek formal dalam penelitian ini menggunakan teori konflik, bentuk konflik, dan faktor penyebab konflik. Teknik pemerolehan data yang digunakan adalah teknik pustaka. Hasil penelitian ini meliputi bentuk konflik dan faktor penyebab terjadinya konflik. Bentuk konflik yang terjadi dalam perbandingan karya ini terletak pada konflik suami dan istri. Faktor penyebab konflik meliputi permasalahan keagamaan dan pekerjaan.

Kata Kunci : chairil gibran ramadhan, keluarga betawi, konflik, s.m. ardan, sastra bandingan 
Pendahuluan

Karya sastra yang mengungkapkan kondisi masyarakat Betawi sangatlah bisa dihitung jari. Tidak banyak pengarangapalagi asli Betawi-yang menulis karyanya dalam lingkup masyarakat Betawi serta penggunaan bahasa Betawi dalam media penyampaian cerita maupun dialog. Pengarang Betawi dalam membuat karya sastra juga memiliki keunikannya sendiri, baik yang hanya menuangkan bahasa Betawi dalam narasi, ungkapan, dan dialog tokoh, atau bisa juga sebaliknya. S.M. Ardan dan Chairil Gibran Ramadhan merupakan dua sastrawan Betawi yang mampu melihat kondisi Betawi dari berbagai keadaan sejak masa silam sampai sekarang. Ardan dan Chairil mampu membuat lukisan peristiwa dengan latar dan tokoh yang identik dengan kehidupan Betawi.

Ardan dan Chairil meski berbeda generasi, keduanya mampu menutupi setiap cerita-dengan tema betawi-satu sama lain bahkan memiliki kekhasan dari cerita masing-masing. Ardan dalam kumpulan cerpen Terang Bulan Terang di Kali melukiskan kisah sehari-hari masyarakat Betawi menggunakan dialek Betawi guna terjalin estetika cerita yang syarat akan kondisi masyarakat Betawi. Lain pula dengan Chairil dalam kumpulan cerpen Sebelas Colen di Malam Lebaran yang mengolah folklor dan mitos melalui peristiwa yang digambarkan di dalam beberapa cerpennya. Penggambaran dari kedua sastrawan Betawi ini masih mempertahankan warna lokal Betawi dalam berbagai segi kehidupan.

Penelitian tentang kumpulan cerpen Terang Bulan Terang di Kali sangat minim.
Volume 3, Nomor 2, Juli 2021

ISSN 2655-3031 (P), 2655-7851 (O)

DOI: http://dx.doi.org/10.29300/disastra.v3i2.4076

Misalnya saja Bahtiar (2018) yang hanya membahas mengenai warna lokal Betawi dalam kumpulan cerpen tersebut. Sedangkan dalam kumpulan cerpen Sebelas Colen di Malam Lebaran lebih banyak membahas mengenai unsur kebahasaan. Ada pula yang membahas mengenai stereotip positif dan negatif seperti Wijanarko (2020) yang mengupas sisi stereotip takhayul, matrealis, senang bergunjing, menjual aset, dan tidak berpendidikan.

Penggambaran dalam kedua kumpulan cerpen tersebut juga membahas beberapa permasalahan mengenai keluarga Betawi. Keluarga Betawi memiliki berbagai macam perbedaan antara satu dan lainnya. Keluarga Betawi juga sama seperti keluarga pada umumnya yang mempunyai suami, istri, dan juga anak. Friedman (2010) mengatakan bahwa keluarga merupakan satu atau lebih individu yang tergabung karena ikatan tertentu untuk saling membagi pengalaman dan melakukan pendekatan emosional serta mengidentifikasi diri mereka sebagai bagian dari keluarga.

Problematika yang ditimbulkan dalam keluarga Betawi menyesuaikan dengan kondisi yang ada seperti suami dan istri atau bisa pula orang tua dan anak. Konflik terjadi karena beberapa hal yang sudah menjadi kebiasaan dalam suatu masyarakat tertentu —masyarakat Betawi - di tiap wilayah tertentu di mana masyarakat itu tinggal. Konflik dalam setiap keluarga memliki ciri-ciri tertentu yang dapat membedakan unsur apa saja yang menyebabkan konflik itu terjadi.

Beberapa persoalan telah diurai di atas. Tulisan ini akan membahas bagaimana 
konflik keluarga Betawi itu terjadi, selain itu juga membandingkan konflik keluarga Betawi dalam kedua cerpen karya Ardan dan Chairil. Peneliti dalam hal ini memilih cerpen Belum Selesai karya Ardan dalam kumpulan cerpen Terang Bulan Terang di Kali dan cerpen Dzikir karya Chairil dalam kumpulan cerpen Sebelas Colen di Malam Lebaran sebagai representatif dari masingmasing pengarang yang mengungkapkan konflik keluarga Betawi dengan berbagai perspektif. Tujuan penelitian ini adalah untuk memperoleh bentuk konflik serta faktor penyebab konflik itu terjadi dalam kedua karya yang dibandingkan.

Konsep mengenai konflik dalam kaitan sastra berhubungan dengan tokoh di dalam karya. Konflik bisa terjadi karena perseorangan maupun suatu kelompok masyarakat. Craib (1992) menyatakan bahwa teori konflik melibatkan diri dengan perbandingan yang tidak jelas untuk membangun gambarannya tentang dunia sosial. Perbandingan dalam konflik bukan semata-mata persoalan yang salah saja. Terkadang kebenaran juga menjadi sebuah perbandingan bagaimana sebuah konflik itu muncul ke permukaan. Hal tersebut selaras dengan ungkapan Talcott Parsons dalam buku Sehandi (2014) bahwa konflik tidak selalu bersifat negatif, dalam masyarakat terbuka dan plural, konflik dapat pula memperkuat antarhubungan. Konflik bisa muncul dari persoalan benar dan salah tegantung bagaimana permasalahan itu hadir. Konflik juga tak selamanya bersifat negatif, konflik terkadang mampu membuat orang lain merasakan kebaikan atau kebermanfaatan terhadap konflik yang tercipta.
Volume 3, Nomor 2, Juli 2021

ISSN 2655-3031 (P), 2655-7851 (O)

DOI: http://dx.doi.org/10.29300/disastra.v3i2.4076

Sehandi (2014) juga menambahkan bahwa secara umum konflik dalam karya sastra dapat digolongkan menjadi dua jenis, yakni konflik internal dan konflik eksternal karya sastra. Konflik internal adalah permasalahan yang terjadi dalam diri seorang tokoh yang mengalami pergulatan dalam dirinya sendiri tanpa disebabkan atau dipengaruhi orang lain di sekitarnya. Sedangkan konflik eksternal adalah permasalahan yang terjadi karena faktor lain di luar diri sang tokoh. Dengan kata lain, konflik internal maupun eksternal dalam karya sastra dipengaruhi oleh berbagai hal yang berkaitan dengan asal konflik itu muncul.

Brommel dan Galvin (1986) memaparkan bahwa konflik dalam keluarga dikategorikan menjadi dua, yaitu yang berfokus pada isu-isu mendasar juga yang kurang berfokus pada isu dasar. Isu mendasar atau sentral terkait dengan agama, kepemilikan anak, dan pendidikan. Sedangkan konflik yang tidak berfokus pada isu utama adalah hal-hal yang terkait dengan aktivitas sehari-hari seperti keputusan untuk berlibur atau pembagian tugas pekerjaan.

Wirawan (2010) memaparkan bentuk-bentuk konflik berdasarkan sifatnya terbagi dua. Pertama, konflik konstruktif yang terjadi karena perbedaan pendapat antar kelompok maupun antar sosial dalam membahas suatu masalah. Kedua, konflik destruktif yang disebabkan adanya sifat tidak senang dan biasanya disertai dengan rasa dendam kepada kelompok atau orang lain.

Berdasarkan pelaku yang berkonflik terbagi menjadi dua. Pertama, konflik vertikal, yaitu konflik yang terjadi antar 
sesama struktur kelompok masyarakat yang hierarki seperti konflik yang terjadi antara suami sebagai kepala keluarga dan istri yang berada di struktur bawahannya. Kedua, konflik horizontal yang terjadi antara individu atau kelompok yang mempunyai kedudukan yang sama dalam masyarakat maupun keluarga. Contohnya seperti konflik suami dengan ayahnya atau suami dengan mertuanya.

Robbins (2008) memaparkan penyebab terjadinya konflik karena adanya suatu keadaan yang menjadi latar belakang kondisi itu (accident conditions). Sumber terjadinya konflik dalam kondisi tersebut sebagai penyebab terciptanya konflik. Konflik terdiri dari tiga unsur, yakni: struktur, komunikasi, dan variabel pribadi. Berdasarkan hal tersebut, penelitian ini bertujuan untuk mengetahui bentuk-bentuk konflik serta faktor penyebab munculnya konflik dalam cerpen Belum Selesai karya S.M. Ardan dan Dzikir karya Chairil Gibran Ramadhan.

\section{Metode Penelitian}

Sumber primer yang digunakan adalah kumpulan cerpen Terang Bulan Terang di Kali karya S.M. Ardan yang diterbitkan oleh Masup Jakarta pada tahun 2007. Selain itu, termasuk juga kumpulan cerpen Sebelas Colen di Malam Lebaran karya Chairil Gibran Ramadhan yang diterbitkan Masup Jakarta pada 2008. Sementara itu, untuk sumber selain dua buku di atas, ada pula jurnal, artikel, bukubuku lainnya terkait penelitian yang dibahas menjadi bahan sekunder untuk menunjang penelitian.

Metode yang digunakan adalah metode kualitatif. Sukandarrumidi (2014)
Volume 3, Nomor 2, Juli 2021

ISSN 2655-3031 (P), 2655-7851 (O)

DOI: http://dx.doi.org/10.29300/disastra.v3i2.4076

menjelaskan bahwa metode penelitian ilmiah pada dasarnya merupakan cara ilmiah untuk mendapatkan data dengan tujuan dan kegunaan tertentu. Hal tersebut sesuai dengan pemaparan Syamsuddin (2015) bahwa tujuan pokok penelitian kualitatif adalah menggambarkan, mempelajari, dan menjelaskan fenomena yang tergambar dalam teks. Teks dalam penelitian ini merupakan data primer. Data diperoleh melalui pembacaan intensif dan melakukan pencatatan. Kemudian, data dianalisis dengan metode deskriptif kualitatif berdasarkan dengan teori konflik.

Pendekatan yang digunakan adalah sastra bandingan, yaitu dengan cara membandingkan cerpen yang satu dengan cerpen lainnya. Sutarto (2013) menjelaskan bahwa pada umumnya disiplin sastra bandingan dikaitkan dengan telaah antara dua kesusastraan atau lebih. Pradopo (2002) menjelaskan prinsip metode perbandingan ialah persamaan antara karya sastra satu dengan karya sastra yang lain. Perbandingan tersebut difokuskan pada konflik keluarga Betawi yang terjadi dalam kedua cerpen tersebut. Analisis data pada penelitian ini merupakan teknik analisis model interaktif yang dikemukakan Miles dan Huberman seperti yang dimuat Nugrahani (2014). Analisis data model interaktif ini memiliki tiga komponen, yaitu: (1) reduksi data, (2) sajian data, dan (3) penarikan kesimpulan/verifikasi.

Reduksi data dalam penelitian ini yaitu merangkum, mengidentifikasi hal-hal yang menyebabkan konflik keluarga. Sajian data dalam penelitian ini berupa sajian data konflik keluarga yang telah diidentifikasi. Kesimpulan atau verifikasi ini merupakan pemeriksaan kembali data dengan cermat 
agar tidak terjadi kesalahan dengan fakta yang sebenarnya.

\section{Hasil dan Pembahasan}

Ratna (2007) mengungkapkan bahwa kebebasan sekaligus kemampuan karya sastra untuk memasukkan hampir seluruh aspek kehidupan manusia menjadikan karya sastra sangat dekat dengan aspirasi masyarakat. Hal tersebut dapat ditandai melalui konflik atau permasalahan yang biasa muncul dalam dalam karya sastra. Konflik dalam kaitannya dengan orang luar, keluarga, maupun diri sendiri. Konflik keluarga Betawi ini dapat dianalisis dari kehidupan masyarakat betawi yang digambarkan oleh Ardan dan Chairil.

\section{Konflik Cerpen Belum Selesai}

Cerpen Belum Selesai karya Ardan ini mengungkapkan bahwa konflik dimulai sejak awal cerita itu dinarasikan. Pertunangan adik perempuan Patmah dibatalkan oleh pihak laki-laki karena tidak mau mempunyai keluarga besar yang di dalamnya ada pencuri. Keluarga pencuri yang dimaksudkan di sini ditujukan pada suami Patmah. Seperti dalam kutipan di bawah ini.

Pertunangan adik perempuannya putus. Pembatalan ini atas permintaan pihak laki-laki. Alasannya tidak mungkin tidak diterima.... Sesudah itu didesuskan, bahwa alasan yang agak lemah ini dasarnya adalah karena pihak laki-laki tak mau mempunyai keluarga pencuri. (Ardan:2007)

Pembatalan pertunangan tersebut membuat hati Patmah menjadi tersakiti karena mengetahui bahwa sesungguhnya pembatalan terjadi akibat suaminya yang
Volume 3, Nomor 2, Juli 2021

ISSN 2655-3031 (P), 2655-7851 (O)

DOI: http://dx.doi.org/10.29300/disastra.v3i2.4076

masuk tahanan karena mencuri. Pekerjaan sebagai pencuri memang tidak seharusnya diinginkan oleh setiap orang termasuk kepala rumah tangga. Konflik yang dialami Patmah ini dimulai memang karena suaminya yang masuk penjara karena mencuri. Pada hari kebebasan suaminya Patmah merasa bahagia karena ia akan bertemu lagi dengan suaminya. Di sisi lain ia merasakan sakit hatinya terhadap perkataan orang mengenai suaminya yang seorang pencuri. Terlebih bukan hanya orang di luar keluarganya yang mengatakan seperti itu. Adik Patmah juga membuatnya merasa sedih.

Suatu hari uangnya hilang. Dia tanyakan adik laki-lakinya apa ada melihat atau menemukan atau barangkali juga memakai uangnya. Tapi jawaban adikknya begitu mengagetkan: "Laki lu bole tukang nyolong!" ... "Gue bukan bangse laki lu tukang nyolong. Tau nggak?" (Ardan:2007)

Perasaan sedih dirasakan Patmah karena perkataan adiknya sendiri tepat di hari kebahagiannya menanti suaminya bebas dari penjara. Konflik yang terjadi di awal cerita tersebut menjadikan kekuatan tersendiri bagi Patmah menerima kesalahan suaminya sejak satu tahun silam. Konflik yang dibagun sejak awal menunjukan bagaimana Keluarga Betawi ketika salah satu keluarganya membuat kesalahan yang fatal sehingga masuk penjara maka ada saja yang tidak bisa menerima dan memberikan tanggapan negatif kepada keluarganya. Selain dari adik Patmah, ketidaktahuan saudara-saudara Patmah, ikut membuat Patmah merasakan kesedihan. 
Atau datang saudara-saudaranya yang belum tau halnya: "Lakinye ke mane, Patmah?" Pertanyaan tegur sapa ini, pertanyaan yang sopan yang menyatakan persaudaraan ini, bahkan ejekan terasa. Tapi lama-lama hatinya menjadi biasa dan tabah: "Di bui." Ketegasan jawab itu mengejutkan yang bertanya... Tapi Patmah permisi pada tamunya, masuk sebentar purapura ada yang perlu diambil atau dikerjakan. Namun sang tamu pun maklum apa yang sebenarnya terjadi di dalam kamar itu, Patmah menangis! (Ardan: 2007)

Konflik tersebut berasal dari saudara Patmah yang belum tahu keberadaan suaminya Patmah. Konflik batin yang Patmah alami tetap membuat ia bahagia di hari kebebasan suaminya. Setelah suami Patmah bebas, konflik dalam keluarganya muncul lagi dengan permasalahan yang sama, yaitu pekerjaan.

Lambat tapi tegas terdengar suara Kosim:

"Lu jangan kerje lagi!"

Patmah mau menyangkal: "Abis ..."

"Lu nggak bole kerja, abis perkare." Pembicaraan yang telah berubah menjadi perdebatan yang ditutup dengan bentakan suaminya ini, tidak diduganya pada hari kebebasan suaminya ini. (Ardan: 2007)

Kutipan di atas menjelaskan Kosim merasa harus dialah yang harus mencari nafkah bukan istrinya. Larangan suami kepada istri untuk bekerja merupakan hal yang sering ada dalam kehidupan sebuah keluarga. Seperti kata Chaer (2015) bahwa tiap keluarga tentu memiliki tugas dan perannya masing-masing, namun secara umum tugas tersebut sama dalam setiap
Volume 3, Nomor 2, Juli 2021

ISSN 2655-3031 (P), 2655-7851 (O)

DOI: http://dx.doi.org/10.29300/disastra.v3i2.4076

masyarakat. Ayah bertugas mencari rezeki untuk menghidupi seluruh keluarga, ibu berfungsi mengurus dan mengatur kehidupan keluarga, sedangkan anak bertugas turut mengikuti kehidupan dengan belajar. Pada dasarnya suami tidak mau dinafkahi oleh istrinya sendiri karena merasa tanggung jawab tersebut ada di pundak suami, kepala keluarga. Seperti dalam percakapan Patmah dan Mak Minah.

Dan datanglah Patmah pada Mak Minah. "Turutin dulu kemauannye." "Tapinye ..." "Eee, eee, lelaki nggak mau diempanin bini, ngerti?" (Ardan: 2007)

Kosim dalam keadaan belum mendapatkan kerja seharusnya berpikir bagaimana harus menghidupi anak dan istrinya. Ketika ia melarang istrinya bekerja maka ia harus mendapatkan uang demi terbutuhi kebutuhan hidup keluarganya.

"Sebelon Abang dapet, biar Pat..."

Kosim ikut tunduk. Patmah makin berani:

"Iye, Patmah berenti deh kalu Abang ude dapet kerjaan."

Kosim diam. Dengan ketakutan Patmah menanti. Kosim masih diam sejurus lama.

"Ho-oh deh!" Lantas Kosim berlalu. Patmah bingung. (Ardan: 2007)

Kutipan di atas menjelaskan bahwa Kosim yang terdesak dan tak dapat berbuat banyak karena belum mendapatkan pekerjaan sehingga ia memutuskan untuk menerima keputusan Patmah yang ingin bekerja. Seorang suami harus bisa mengambil sikap di tengah kondisi terdesak sekalipun. Konflik mulai meredam dengan dialog tokoh Kosim yang mengiyakan istrinya. Tapi Patmah masih bingung 
dengan jawaban Kosim yang tidak dengan kepatian. Keadaan seperti itu, seharusnya membuat suami semakin giat mencari pekerjaan dan tidak diam saja. Hal ini sejalan dengan tokoh Kosim yang terus mencari pekerjaan.

"Tulung masupin, Sar!"

"Gue bukan nggak mau nulung, Sim."

"Tege lu, Sar, ame temen."

"Gue sih ngasi aje. Tapi..." Kosim segera bangkit meninggalkan Amsar yang lantas memburunya cepat. (Ardan: 2007)

Kutipan tersbut menjelaskan bahwa Kosim gagal mendapatkan pekerjaan. Tidak mendapatkan pekerjaan bukan berarti gagal selamanya. Masih ada kesempatan yang bisa dibuat agar pekerjaan bisa didapatkan. Kosim yang hari itu langsung pulang ke rumah karena gagal menjadi tukang becak. Ia membuat Patmah kebingungan, sebagaimana tampak pada kutipan berikut.

"Lu kenape nggak kerja?"

"Kan Abang bilang..."

"Mane bisa idup kalu nggak kerja?

Lu musti ngerti, tau?"

"Tapi tadi pagi Abang bilang kan..."

"Ho-oh deh, mentang-mentang laki nggak kerja disalahin terus"

"Bukan gitu..." "Bukan gitu pegimane?"

Patmah diam ketakutan. Kosim bertambah kesal (Ardan: 2007)

Konflik dalam suami istri di atas adalah suatu hal yang sering terjadi. Adu mulut yang dilakukan oleh suami dan istri biasanya karena satu di antara duanya merasa kesal karena sesuatu hal. Perdebatan yang terjadi antara Patmah dan
Volume 3, Nomor 2, Juli 2021

ISSN 2655-3031 (P), 2655-7851 (O)

DOI: http://dx.doi.org/10.29300/disastra.v3i2.4076

Kosim membuat konflik semakin memuncak. Suami yang tidak mau mengalah ini disebabkan oleh banyaknya pikiran. Hal tersebut juga karena lelah mencari pekerjaan yang tak kunjung didapatkan. Konflik tersebut membuat Patmah menjadi serba salah. Simak kutipan berikut.

"Kite musti pegimane dong? Begini salah, begitu salah."

"Turutin aje omongannye dulu."

"Nyang mane mau diturut? Mau kerja gak dikasih. Orang kagak kerja diomelin. Pulang terus marahmarah.” (Ardan: 2007)

Dialog di atas membuktikan bahwa konflik yang terjadi antara Patmah dan Kosim pada bagian sebelumnya membuat Patmah bingung atas pemikiran suaminya yang terkadang berubah-ubah. Dengan saran Mak Minah yang kesekian kali Patmah menjadi paham apa yang harus dilakukan. Seorang lelaki punya tindakan yang matang yang sudah dipikirkannya secara mendalam.

"Abang pikir mendingan dagang aje."

Patmah melirik, serasa mimpi:

"Mau dagang ape, Bang?"

"Ah, apa aje sih, Cuma modalnya nih." (Ardan: 2007)

"Ade temen abang nyang ude janji nyanggupin ngasi pinjem"

Hampir tidak percaya Patmah akan pendengarannya, tapi:

"kemarin die janjiin, sekarang dateng lagi, katanye.” (Ardan: 2007)

Kutipan di atas merupakan sebuah peleraian dari permasalahan yang ada. Kosim mulai sadar bahwa ketika tak mendapatkan pekerjaan ia harus memikirkan dengan matang apa yang 
selanjutnya harus ia lakukan. Kutipan tersebut menandakan bahwa konflik mulai meredam perihal pekerjaan yang akan Kosim lakukan adalah berdagang. Permasalahan yang muncul lebih kepada modal untuk berdagang. Kosim sadar bahwa menjual barang berharga yang ia miliki demi mendapatkan modal tidaklah baik. Akhirnya, Kosim memilih meminjam kepada temannya untuk modal berdagang.

Konflik keluarga Betawi dalam cerpen Selesai tersebut diawali dari adik Patmah yang tidak jadi bertunangan akibat suaminya Patmah seorang pencuri. Patmah menjadi objek dari semua konflik yang ada. Adik dan saudaranya menjadi konflik semakin bertambah. Konflik itu semakin meningkat dengan bebasnya Kosimsuami Patmah-yang melarang Patmah untuk bekerja. Konflik mulai mereda dengan kesadaran Kosim yang ingin bekerja bahkan ingin memulai berdagang dengan modal dari pinjaman temannya.

\section{Konflik Cerpen Dzikir}

Lain halnya dengan cerpen Dzkiri karya Chairil Gibran Ramadhan. Cerpen tersebut di awal memunculkan sebuah kondisi di sebuah kampung yang setiap Ahad minggu terakhir pergi dzikir dengan pakaian serba putih. Cerpen ini tidak langsung memulainya dengan konflik tapi memunculkan kondisi terlebih dahulu sebagai permulaan munculnya konflik. Setelah pemunculan dzikir tiap minggu di akhir bulan ini merambat kepada pola pikir suatu masyarakat terkait dengan acara dzikir yang diikuti oleh banyak orang. Sehingga penyebutan orang yang tidak pernah ikut dzikir berjamaah ini adalah orang yang islamnya kurang.
Volume 3, Nomor 2, Juli 2021

ISSN 2655-3031 (P), 2655-7851 (O)

DOI: http://dx.doi.org/10.29300/disastra.v3i2.4076

Kegiatan dzikir massal itu pun dengan cepat menjadi mode, bahkan muncul anggapan orang yang tidak ikut pergi ketinggalan mode, tidak menghidupkan Islam dan disebutsebut - sambil berbisik-bisik tentusebagai "kurang Islam". (Ramadhan: 2008)

Pola pikir masyarakat Betawi yang kebanyakan orang Islam ini sesungguhnya muncul karena merasa dengan beribadah akan menambahkan keimanan seseorang. Masyarakat Betawi menilai ibadah sekecil apapun kalau itu baik ya harus dilakukan. Hal ini selaras dengan ungkapan Dr. Snouck Hurgrounje (Amsir: 2011) yang menyatakan bahwa di Nusantara ini tidak ada yang lebih religius daripada orang Betawi. Paradigma yang timbul bahwa ketika orang tidak mengikuti dzikir maka ia disebut islamnya kurang atau juga tidak menerapkan agama Islam dengan benar. Sikap seperti ini sesungguhnya menurut penulis merupakan sikap yang terusmenerus ada dalam masyarakat Betawi. Sifat tersebut muncul untuk menggungguli bahwa yang melakukan kegiatan dzikir tersebut keislamannya menjadi sempurna, meski tidak tahu tujuan di balik dzikir bersama itu.

Selaras dengan Hurgrounje, Taendiftia (1996) juga menegaskan bahwa masyarakat Betawi kebanyakan adalah pemeluk agama Islam yang taat. Oleh karena itu, tidak heranlah bila tata cara kehidupan mereka sehari-hari pun bernafaskan Islam. Begitu juga dengan Blackburn (2011) menjabarkan ciri khas orang Betawi. Pertama, orang Betawi beragama Islam dan memiliki reputasi sebagai muslim fanatik. Kedua, orang 
Betawi berbicara dalam bahasa mereka sendiri, sebuah dialek Melayu Betawi yang khas.

Konflik dimulai ketika sang istri masak seadanya karena ada kegiatan berdzikir setiap hari Ahad pagi. Dzikir, pada dasarnya adalah kegiatan yang baik dilakukan oleh umat Islam. Kegiatan dzikir bisa saja menjadi kebaikan jika tidak mengabaikan kewajiban lainnya.Seperti yang digambarkan pada kutipan di bawah ini:

Maka, setiap Ahad minggu terakhir, sudah tujuh bulan ini aku terbiasa makan siang seadanya. Biasanya pagi-pagi sekali selepas sholat Subuh isteriku sudah menanak nasi disusul telur dadar dan acar kuning atau tempe goreng dan tahu dimasak bumbu tauco atau ayam goreng dan sambal terasi. (Ramadhan: 2008)

Kutipan di atas adalah permulaan konflik itu muncul. Konflik disajikan dengan ungkapan perasaan tokoh Aku melalui narasi yang disajikan serta dialog antara Aku dan isterinya. Permasalahan yang disajikan berupa makanan yang dimasak isteri pada saat suaminya libur kerja atau hari Ahad hanya itu-itu saja. Konflik ditambah melalui tokoh isteri yang menanggap suaminya melarang sang isteri beribadah.

Seringkali kami bertengkar hari itu. Isteriku yang selalu saja merasa benar dalam kejadian ini akan kembali memojokkanku karena katanya aku melarangnya beribadah. Ia yang bagiku cukup cerdas itu ternyata juga bisa begitu bodoh bila melihat suatu masalah. (Ramadhan: 2008)
Volume 3, Nomor 2, Juli 2021

ISSN 2655-3031 (P), 2655-7851 (O)

DOI: http://dx.doi.org/10.29300/disastra.v3i2.4076

Penggambaran di atas menerangkan tentang pertengkaran antara suami dan isteri karena permasalahan beribadah. Beribadah memang hak seseorang untuk melakukannya. Suami juga mempunyai hak yang harus isteri mengerti dan patuhi bukan karena melarangnya beribadah tapi lebih kepada ibadah itu dilakukan semata-mata karena pencipta bukan hanya ikut-ikutan belaka. Ibadah yang dilakukan sang isteri seharusnya tidak sampai membuat suami menjadi tak terurus. Seperti kutipan berikut.

"Guah kagak ngelarang eluh pergi dzikir. Apah pernah guah ngomong begituh? Pan kagak! Guah cuman keberatan kalo eluh pegih tiap abis bulan cuman ninggalin lauk seadanyah sampe makan guah jadi kagak keurusan.” (Ramadhan: 2008)

Konflik antara suami dan isteri semakin meningkat karena sang isteri yang membandingkan suaminya dengan orang lain untuk persoalan ibadah. Perbandingan tersebut tidak sepatutnya dilayangkan seorang isteri karena dapat memicu pertengkaran yang lebih besar. Simak kutipan berikut.

"Emang! Guah kereja hari-harinyah! Lagian nyang eluh maksud bapakbapak di sini entuh siapah? Mang Jenih, nyang setiap pulang dzikir langsung ngutak-ngatik nomer togel ama hari-harinyah Cuma mancing sambil nungguin orang bayar kontrakan? Wak Amat ama Wak Ni'ih nyang rajin dzikir, tapi rajin juga main judi ayam ama koprok kalo pasan ada ot dan hari-harinyah cuman kereja kalo ada nyang manggil doangan? Atawa wadonnya Ce Iyah, nyang dzikir jalan terus tapi 
begunjingannyah juga jalan terus?" (Ramadhan: 2008)

Kutipan di atas menjelaskan konflik yang memuncak antara suami dan isteri. Melalui dialog antara tokoh Aku dan isteri permasalahan semakin besar dan panjang karena kedua tokoh masing-masing berpegang teguh pada argumennya. Pada permasalahan di atas terdapat dua hal yang menjadi pertengkaran semakin besar yaitu makanan dan dzikir. Makanan bukan sebab utama, dzikirlah yang menjadikan konflik tersebut menjadi semakin besar. Sang suami bersikukuh bahwa berdzikir baik apabila dilakukan karena niat yang ikhlas bukan ikut-ikutan saja. Banyak orang yang selesai dzikir bersama tetap melakukan keburukan sesudahnya. Isterinya tetap pada pendiriannya bahwa suaminya hanya memikirkan perut saja tidak mau untuk rajin beribadah.

Cerper Dzikir di atas menandakan bahwa konflik terjadi antara suami dan isteri. Konflik tersebut berkaitan dengan ritual agama Islam, yaitu dzikir. Dzikir pada dasarnya adalah kegiatan yang positif, namun yang dilakukan oleh sang isteri adalah ikut-ikutan saja dan tidak tulus. Hal tersebut ditambah dengan perkataan sang isteri setelah selesai berdzikir yang membandingkan suaminya dengan orang lain.

\section{Perbandingan Kedua Cerpen}

Kedua cerpen tersebut memiliki kesamaan dan perbedaannya. Persamaan yang jelas terasa bahwa yang dikisahkan sama-sama keluarga Betawi melalu narasi yang disajikan dan juga dialog tokoh yang menggunakan dialek Betawi. Lebih
Volume 3, Nomor 2, Juli 2021

ISSN 2655-3031 (P), 2655-7851 (O)

DOI: http://dx.doi.org/10.29300/disastra.v3i2.4076

khususnya konflik kedua cerpen tersebut memiliki perbandingan yang cukup berbeda. Bentuk konflik dalam cerpen Belum Selesai lebih kepada konflik perseorangan. Cerpen ini membahas konflik tokoh Patmah dengan adiknya secara singkat. Tokoh Patmah juga berkonflik dengan suaminya, Kosim. Sedangkan dalam cerpen Dzikir tokoh Aku sebagai suami berkonflik dengan isterinya.

Penyebab konflik dalam cerpen Belum Selesai disebabkan oleh pekerjaan suami sebagai pencuri. Selanjutnya, konflik berkembang berkenaan dengan suami yang belum mendapatkan pekerjaan. Sedangkan, dalam cerpen Dzikir, penyebab konflik adalah makanan yang disajikan isteri hanya beberapa karena isteri lebih memilih berdzikir setiap Ahad akhir bulan. Konflik terus berkembang melalui dialog tokoh Aku dan Isteri permasalahan dzikir.

Penanganan konflik dalam cerpen Belum Selesai dilakukan tokoh Kosim dengan meminjam uang kepada temannya sebagai modal ia berdagang. Sedangkan, dalam cerpen Dzikir penanganan konflik diakhiri dengan narasi tokoh aku yang mengatakan bahwa ibadah dan ajaran agama tidak salah yang salah orangorangnya. Konflik berakhir dengan narasi tersebut bukan dengan dialog antartokoh seperti pada konflik yang memuncak.

\section{Simpulan}

Konflik dalam cerpen Belum Selesai Konflik dalam cerpen Belum Selesai karya S.M. Ardan dan cerpen Dzikir karya Chairil Gibran Ramadhan ini memiliki permasalahannya sendiri. Konflik dalam cerpen Belum Selesai dimunculkan oleh tokoh yang merupakan suami dari Patmah 
yang masuk penjara karena mencuri. Konflik tersebut semakin meningkat mulai dari perkataan orang-orang, asumsi yang orang sampaikan terkait suami Patmah yang masuk penjara membuat konflik ini terus-menerus muncul dalam setiap perkembangannya. Konflik tersebut meningkat saat Kosim yang keluar dari penjara begitu sering memarahi Patmah karena tidak mau dinafkahi dari hasil pekerjaan seorang istri.

Konflik dalam cerpen Dzikir lebih kepada permasalahan kegiatan agama yang menjadi dasar konflik ini terus berlanjut. Konflik dirasakan oleh sang suami yang tidak suka kalau setiap istrinya pergi berdzikir setiap bulan hanya memasak seadanya. Hal inilah yang menjadikan konflik bahwa istri boleh melakukan kegiatan agama selama itu juga ia telah melayani suami dengan baik. Kegiatan keagamaan memang baik terlebih lagi dengan melayani suami secara utuh agar keletihan suami selama bekerja bisa terbayarkan.

Kedua cerpen tersebut memiliki konflik dengan tokoh yang sama yaitu suami dan istri dalam keluarga Betawi. Perbedaan keduanya terletak pada konflik yang disajikan. Konflik yang disajikan ini berbeda satu sama lain. Konflik dalam cerpen Belum Selesai lebih kepada persoalan pekerjaan suami yang awalnya mencuri dan bersifat keras terhadap istrinya menjadi pekerja yang mau berusaha dan menjadi baik karena tuntutan bahwa seorang suami harus manfkahi istrinya. Konflik dalam cerpen Dzikir lebih menekankan pada aspek keagamaan, yaitu dzikir yang menjadi awal permasalahan itu menjadi lebih meningkat.

\section{Daftar Pustaka}

Amsir, Saifuddin. (2011). Budaya Betawi Reflika Ajaran Islam Sejati. Prosiding Kongres Kebudayaan Betawi 2011. Jakarta, 5-7 Desember 2011.

Ardan, S.M. (2007).Terang Bulan Terang di Kali: Cerita Keliling. Jakarta. Depok: Masup Jakarta.

Bahtiar, Ahmad. (2018). "Sastra Warna Lokal Betawi Sebagai Bahan Pembelajaran Bahasa Indonesia untuk Penutur Asing (BIPA)". $J$. Insania, 23(1), 80-91.

Blackburn, Susan. (2011). Jakarta: Sejarah 400 Tahun. Jakarta: Masup Jakarta.

Brommel, Bernadr J dan Kathleen M. Galvin. (1986). Family Communication, Cohesion, and Change. USA: Foresman \& Company.

Chaer, Abdul. (2015). Betawi Tempo Doeloe. Depok: Masup Jakarta.

Craib, Ian. (1992). Teori-teori Sosial Modern: dari Parson sampai Habermas. Jakarta: Rajawali Pers.

Friedman, M. (2010). Buku Ajar Keperawatan Keluarga: Riset, Teori, dan Praktik. Jakarta: EGC.

Nugrahani, Farida. (2014). Metode Penelitian Kualitatif dalam Penelitian Pendidikan Bahasa. Surakarta: Nugrahani.

Pradopo, Rachmad Djoko. (2003) Beberapa Teori Sastra, Metode, Kritik, dan Penerapannya. Yogyakarta: Pustaka Pelajar. 
Ramadhan, Chairil Gibran. (2008). Sebelas Colen di Malam Lebaran. Depok: Masup Jakarta.

Ratna, Nyoman Kutha. (2007). Teori, Metode, dan Teknik Penelitian Sastra. Yogyakarta: Pustaka Pelajar.

Sehendi, Yohanes. (2014). Mengenal 25 Teori Sastra. Yogyakarta: Ombak.

Sp. Robbins dan Judge. (2008). Perilaku Organisasi. Jakarta: Salemba.

Sukkandarrumidi dan Haryanto. (2014) Dasar-dasar Penulisan Proposal Penelitian. Yogyakarta: Gadjah Mada Universit Press.

Sutarto, Ayu. (2013). Sastra Bandingan dan Sejarah Sastra Indonesia. J. Kritik, 4(3), 27-60.

Syamsuddin dan Vismaian Damaianti. (2015). Metodologi Penelitian Bahasa. Bandung: Remaja Rosdakarya.
Volume 3, Nomor 2, Juli 2021 ISSN 2655-3031 (P), 2655-7851 (O) DOI: http://dx.doi.org/10.29300/disastra.v3i2.4076

Taendiftia, Emot Rahmat, dkk. (1996). Gado-gado Betawi. Jakarta: Grasindo.

Wijarnako, Dayat dan Syarif Hidayatullah. (2020). Perlawanan Penulis Betawi Terhadap Stereotip Negatif Masyarakat dalam Cerita Pendek. J. Peta, 10(1), 10-23.

Wirawan. (2010). Manajemen Konflik. Jakarta: Salemba. 